\title{
ESTABLISHMENT OF AN INTERNATIONAL CRIMINAL COURT
}

\author{
Steven J. Gerber
}

It cannot be overemphasized how historic the negotiations to establish a permanent International Criminal Court (ICC) have been. Over 120 states have participated in the process and not one of them questions the need for a permanent ICC to try individuals accused of the most serious international crimes of genocide, crimes against humanity or serious violations of the laws and customs of war (war crimes). In addition, hundreds of non-governmental organizations (NGOs) participate in the NGO Coalition for an International Criminal Court (CICC). ${ }^{1}$

Over the last several months, some of the most supportive governments, known among themselves as the like-minded, ${ }^{2}$ and many of the NGOs have become increasingly dissatisfied with several positions taken by the United States government in the negotiations to establish an ICC. These positions include the role of the United Nations Security Council in the Court's jurisdiction, and whether the Court will have an Independent Prosecutor authorized to initiate investigations and prosecutions on his or her own initiative.

In fact, there have been comparisons between the ICC negotiations and the campaign to ban landmines. In the case of the landmine treaty, the NGO coalition and the states pushing for the treaty made a strategic decision to get what they considered to be the best treaty, even if the United States would not sign. A similar strategy, to push for the most effective and fair court even if the United States will not join, has been discussed as a possible route if the United States does not change its positions on several key issues.

Unfortunately, an ICC without United States participation is unlikely to succeed. It will not have a police force of its own to enforce its decisions and apprehend indicted individuals. The court will depend on the

- J.D., M.A., Director of the International Criminal Court Project of the World Federalist Association and Coordinator of the Washington Working Group on the ICC.

1. For more information on the Coalition for an ICC, see http://www.igc.apc.org/icc, call (212)599-1320 or write CICC, 777 U.N. Plaza, New York, NY 10017.

2. The like-minded countries are a group of approximately forty countries that have pushed ICC negotiations forward and include many United States allies, such as Canada, Australia, Germany, Italy and other countries located in Europe, Latin America and Africa. 
cooperation of states party to the treaty establishing the Court. The negotiating states have still not determined what to do when a state fails to cooperate with the Court.

The ICC will be effective only if the political will of the international community is behind it. One of the most important methods to enforce compliance will be for other states to pressure the noncomplying state to meet its treaty obligations. If the United States government does not participate in the ICC, who will apply political pressure to cooperate with the Court?

After all, it is the United States that has done the most to arrest indicted war criminals in the former Yugoslavia. The European states who are pushing for the best possible treaty, regardless of United States participation, have done little to force the states of the former Yugoslavia to cooperate with the International Criminal Tribunal for the Former Yugoslavia.

The United States has also provided more financial support, seconded personnel, and equipment for the two ad hoc tribunals for the former Yugoslavia and Rwanda than any other country. ${ }^{3}$ If the United States does not participate in the ICC, which countries will provide adequate resources?

Of course, some have argued that even if the United States does not ratify the treaty establishing the ICC, it could still support the work of the court - that it would still be in the interest of the United States to support the ICC. Unfortunately, the United States Senate has already indicated on several occasions that it would consider any effort to cooperate with the court without the Senate's advice and consent to ratification as an attempt to bypass the Senate's constitutional role and would oppose this."

It is true that an effective court, as defined by NGOs, could be created without United States involvement, but such a court is unlikely to be effective. If such a court were created and failed because of lack of United States participation, it would be even worse than if the court had

3. In 1994 and 1995 the:

Several states have contributed assistance to the Tribunal in the form of a loan of personnel to the Office of the Prosecutor. As of 29 May 1995, the Tribunal was receiving seconded personnel from the following states: United States (21 personnel); United Kingdom (5); Netherlands (3); Denmark (2); Norway (2); Sweden (2). . . . In addition, the United States made a contribution of computer systems and related services for the Office of the Prosecutor valued at up to $\$ 2,300,000$. The United Kingdom has also made a contribution of equipment valued at approximately $\$ 30,500$.

4. 1997 State Department Authorization bill (not passed). 
never been created. It would set back the attempt to enforce international humanitarian law. 